\title{
PENERAPAN BAHAN AJAR MATEMATIKA BERBASIS RME TERHADAP KEMAMPUAN PEMAHAMAN KONSEP MATEMATIS DAN SELF-CONFIDENCE SISWA PADA MATERI TRIGONOMETRI
}

\author{
${ }^{1}$ Iryani Dinar \\ ${ }^{1}$ Mahasiswa Program Studi Pendidikan Matematika \\ Fakultas Keguruan dan Ilmu Pendidikan \\ Universitas Muhammadiyah Sukabumi \\ iryanidinar01@gmail.com
}

\begin{abstract}
Abstrak
Tujuan penelitian ini adalah untuk mengkaji penerapan bahan ajar matematika berbasis RME terhadap kemampuan pemahaman konsep matematis dan self-confidence siswa. Metode penelitian dalam penelitian ini adalah metode kualitatif dengan jenis penelitian studi kepustakaan. Dari hasil tersebut dapat disimpulkan bahwa penerapan bahan ajar matematika berbasis RME diharapkan dapat memberi pengaruh positif terhadap kemampuan pemahaman konsep matematis dan self-confidence siswa. Hal ini disebabkan karena (1) Pendekatan pembelajaran RME diimplementasikan terhadap RPP dan bahan ajar berupa LKS dengan langkah-langkah pembelajaran sesuai dengan prinsip dan karakteristik RME, (2) Siswa diberikan kesempatan untuk membangun ide atau pengetahuan mereka sehingga memudahkan ketercapaian indikator-indikator pemahaman konsep matematis siswa, (3) Aktivitas pembelajaran dirancang secara interaktif, mengarahkan siswa pada kemampuan melakukan sesuatu dengan pengalaman dan pengetahuan yang dimilikinya sehingga dapat mengaktifkan self-confidence siswa.
\end{abstract}

Kata Kunci: RME, trigonometri, bahan ajar berbasis RME, kemampuan pemahaman konsep matematis, self-confidence.

\section{PENDAHULUAN}

Pendidikan merupakan kegiatan yang universal dalam kehidupan manusia. Pengembangan segenap potensi dan reformasi menuju arah yang lebih baik dapat diwujudkan melalui pendidikan. Matematika adalah salah satu cabang ilmu pengetahuan yang mempunyai peranan penting dalam berbagai disiplin ilmu, memajukan daya pikir manusia dalam setiap jenjang pendidikan serta sarana yang efektif untuk mencapai keberhasilan pembangunan dalam segala bidang. Namun, fakta di lapangan menunjukkan bahwa hasil belajar matematika siswa saat ini masih tergolong rendah. Tentunya hal tersebut dilatarbelakangi oleh beberapa faktor, salah satunya adalah asumsi kuat yang menyatakan bahwa matematika adalah pelajaran yang sulit, abstrak, dan membosankan karena harus menghafalkan berbagai rumus. Latar belakang lain yang mempengaruhi efektifitas pembelajaran matematika adalah aktivitas kelas cenderung didominasi oleh guru yang lebih sering menggunakan pembelajaran konvensional. Pembelajaran tersebut seringkali meminimalkan dan membatasi keterlibatan siswa untuk aktif. Alhasil, peran siswa menjadi pasif dan suasana kelas menjadi kaku. Siswa hanya memperhatikan, mendengarkan, menulis dan menerima semua yang disampaikan oleh guru.

Ruseffendi (1988) menyatakan bahwa pembelajaran matematika yang baik harus melibatkan siswa secara aktif, dimana siswa mempelajari bagian terbesar dari matematika tidak hanya melalui pemberitahuan didalam kelas saja, namun harus melalui eksplorasi matematik. Surya (2011) menyatakan bahwa pemberian bahan ajar, strategi dan metode yang tepat dengan karakteristik siswa akan meningkatkan hasil belajar. Pada dasarnya siswa sangat membutuhkan pembelajaran yang menyenangkan, inovatif dan menarik bahkan beberapa siswa menyukai pembelajaran yang penuh tantangan untuk memecahkan setiap permasalahan. Guru harus dapat merencanakan secara tepat, memantau dan mengevaluasi proses pembelajaran dan melakukan refleksi. Pembelajaran yang didesain secara interaktif antar sesama murid dan guru, serta kreatif dapat memaksimalkan pemikiran siswa, hasil belajar, motivasi dan membentuk karakter siswa yang mandiri serta percaya diri.

\section{Trigonometri}

Salah satu konsep matematika yang harus dimiliki dan dikuasai oleh siswa yang mulai diajarkan di sekolah menengah hingga ke perguruan tinggi adalah 
trigonometri (Miksalmina, 2013). Konsep trigonometri banyak digunakan sebagai materi prasyarat untuk materi lainnya, seperti dimensi tiga, limit, integral dan materi lainnya (Winarni, 2016). Dalam bidang lain, trigonometri banyak digunakan untuk ilmu-ilmu dasar dan aplikasi dalam fisika, kimia, teknik, geografi, dan astronomi (Nabie, Akayuure, Ibrahim-Bariham, Sofo, 2018).

Namun kenyataannya, mayoritas siswa masih menganggap bahwa trigonometri adalah materi yang sulit untuk dikuasai. Pemahaman konsep yang rendah menjadi penyebab utama kesulitan siswa dalam menyelesaikan soal-soal trigonometri (Agninditya, Sunandar, \& Purwanti, 2014). Siswa mengalami kesalahan konsep perbandingan sudut siku-siku dan perbandingan sudut berelasi (Wulandari \& Puspitadewi, 2015). Penyebab kesalahan yang terjadi antara lain: tidak paham dalam menentukan sisi yang berada di samping, didepan, dan sisi miring suatu sudut pada segitiga siku-siku, dan tidak paham dalam konsep teorema phytagoras sehingga masih kesulitan dalam menentukan nilai perbandingan trigonometri pada segitiga. Dalam pembelajaran, LKS yang diberikan guru juga kurang mengarah pada aktivitas yang seharusnya muncul untuk menekankan konsep, kurang membangun pengetahuan, serta hanya berisikan soal-soal saja (Elianti, Maulina, \& Mailizar, 2014).

Dari uraian-uraian di atas, pemahaman konsep pada materi trigonometri belum sesuai dengan harapan. Padahal, salah satu aspek yang sangat penting didalam matematika adalah pemahaman konsep sehingga perlu dikuasai siswa. Ekaputri (2016) juga menyatakan bahwa pembelajaran matematika harus menekankan pada konsep. Untuk mengatasi permasalahan di atas, diperlukan solusi dalam pembelajaran trigonometri. Salah satunya dengan menggunakan pendekatan matematika realistik.

Menurut Saleh (2012: 51), Pendekatan pembelajaran matematika realistik adalah suatu pembelajaran berfokus pada masalah yang dapat dibayangkan siswa sebagai masalah dalam kehidupan nyata atau masalah didalam dunia mereka. Siswa akan diberikan kesempatan seluas-luasnya untuk membangun konsep-konsep melalui ide atau pengetahuan yang dimilikinya dan bertumpu pada kehidupan sehari-hari sehingga akan lebih lama diingat oleh siswa dan menjadi pembelajaran yang bermakna. Pendekatan pembelajaran ini diharapkan dapat membantu siswa memahami konsep. Desain pembelajaran dalam RPP disusun sesuai dengan kriteria atau karakteristik pendekatan pembelajaran realistik. Untuk menerapkan setiap tahapan dengan maksimal, diperlukan suatu media saat proses pembelajaran. Salah satunya adalah penerapan bahan ajar berupa lembar kerja siswa (LKS). LKS yang digunakan harus membantu dan mempermudah siswa mengkontruksi pengetahuannya dengan waktu yang telah direncanakan dalam kegiatan belajar mengajar. Kemudian, LKS telah disesuaikan dengan prinsip-prinsip dalam pendekatan RME yang dikemukakan Freudential dan karakteristik PMRI yang dikemukakan Marpaung.

Dalam kaitan pentingnya permasalahan yang telah disampaikan tersebut, maka akan diterapkan bahan ajar matematika berbasis RME yang bertujuan untuk meningkatkan kemampuan pemahaman konsep matematika siswa. Tujuan dari penelitian ini adalah untuk mengetahui bagaimana efektifitas penerapan bahan ajar berbasis RME berupa LKS terhadap kemampuan pemahaman konsep matematika dan self-confidence siswa pada materi trigonometri di kelas $\mathrm{X}$.

\section{Pendekatan Pembelajaran RME}

Menurut Mulyono dan Surya (2006) kata realistik berkaitan dengan pendekatan dalam pendidikan matematika yang telah dikembangkan di Nederlands Belanda sejak tahun 1970. Freudenthal mengatakan bahwa matematika adalah aktivitas manusia sehingga harus dikaitkan dengan realita. Pendekatan matematika realistik ini sesuai dengan perubahan paradigma pembelajaran, yaitu revolusi paradigma pembelajaran yang berpusat pada guru menuju paradigma pembelajaran yang berpusat pada siswa atau perubahan paradigma mengajar menuju paradigma belajar. Oleh karena itu, fokus utama pendidikan matematika bukanlah hasil (product) tetapi proses. Pendekatan ini kemudian dikenal dengan Realistik Mathematic Education (RME).

Menurut Freudenthal terdapat 3 prinsip dalam pembelajaran RME, yaitu (1) guideid reinvention yaitu penemuan kembali secara terbimbing, (2) didactical phenomenology yaitu fenomenologi didaktis, dan (3) selfdeveloped models yaitu mengembangkan model-model sendiri. Kemudian, terdapat 10 karakteristik PMRI menurut Marpaung yaitu, (1) pembelajaran interaktif antara siswa dan guru, (2) penyajikan masalah kontekstual sebagai langkah awal pembelajaran, (3) memberi kesempatan seluas-luasnya kepada siswa untuk menyelesaikan permasalahan dengan caranya sendiri, (4) guru memfasilitasi adanya negosiasi dan interaksi, (5) guru menciptakan pendekatan SANI yaitu santun, terbuka dan komunikatif sehingga suasana pembelajaran menyenangkan, (6) prinsip intertinment atau keterkaitan antara materi yang diajarkan, (7) pembelajaran yang berpusat pada siswa, (8) proses pembelajaran bervariasi dan guru bertindak sebagai pembimbing atau fasilitator, (9) memberikan pertanyaan-pertanyaan terbimbing apabila siswa melakukan kesalahan saat menyelesaikan masalah sehingga tidak dimarahi namun cukup disadarkan oleh guru, dan (10) guru memberikan 
apresiasi dengan menghargai keberanian siswa ketika mengutarakan gagasannya.

Dari kegiatan yang dilaksanakan akan diperoleh pemahaman konsep siswa yang disimpan dalam memori jangka panjang (Nurdiyanto, 2019:5). Terpenting dalam pembelajaran tersebut, pengetahuan dikonstruksi oleh siswa sendiri. Ausubel menyatakan bahwa pembelajaran yang bermakna diperoleh dari proses pada struktur kognitif siswa untuk mengaitkan informasi baru pada konsep-konsep yang relevan (Trianto, 2017). Pemahaman konsep yang baik akan diperoleh siswa melalui kegiatan yang dapat mengaitkan antara pengetahuan yang telah dimiliki sebelumnya dengan pengetahuan baru yang sedang mereka pelajari (Balka, Hull, \& Miles, 2012).

\section{Kemampuan Pemahaman Konsep}

Salah satu tujuan pembelajaran matematika di sekolah adalah mengajarkan siswa untuk mampu memahami konsep dan kreatif dalam menyelesaikan masalah tentang matematika. Matematika terdiri dari beragam konsep yang tersusun secara hierarkis, logis, terstruktur dan sistematis mulai dari konsep yang paling sederhana sampai konsep yang paling kompleks (Suherman, 2003:22). Hal ini berarti agar pembelajaran matematika dapat dipahami secara baik maka harus disusun tahapan konsep yang sistematis sehingga tidak ada langkah konsep yang terlewati. Oleh sebab itu, diantara kecakapan matematika yang penting dikuasai siswa adalah pemahaman konsep (conceptual understanding).

Adapun indikator kemampuan pemahaman konsep matematika yang digunakan dalam penelitian ini yaitu berdasarkan Badan Standar Nasional Pendidikan (BNSP) yaitu, (1) kemampuan menyatakan ulang konsep trigonometri, (2) kemampuan mengklasifikasikan perbandingan trigonometeri menurut sifat-sifat, (3) kemampuan memberikan contoh dan bukan contoh dari konsep trigonometri, (4) kemampuan menyajikan konsep trigonometri dalam berbagai representasi, (4) kemampuan mengembangkan syarat perlu atau syarat cukup dari suatu konsep trigonometri, (5) kemampuan menggunakan, memanfaatkan dan memilih prosedur atau operasi tertentu, dan (6) kemampuan mengaplikasikan konsep trigonometri atau algoritma ke pemecahan masalah.

\section{Self- Confidence}

Pendekatan pembelajaran RME secara dominan akan melatih munculnya konsep kepercayaan diri atau self-confidence. Menurut Martyanti (2013), rasa percaya diri atau self-confidence akan mengkondisikan atau memposisikan diri sehingga merasa nyaman untuk melakukan kegiatan, karena dapat melakukan evaluasi dari diri dan lingkungannya untuk dapat mencapai tujuan yang direncanakan sehingga dimaknai sebagai sikap mental yang positif. Penulis memandang bahwa pendekatan pembelajaran RME akan memfasilitasi siswa untuk dapat meningkatkan self-confidence. Terdapat 4 indikator self-confidence (Hendiana, H. Rohaeti, E. dan Sumarmo 2014), yaitu (1) percaya terhadap kemampuan sendiri, (2) bertindak mandiri dalam mengambil keputusan, (3) memiliki konsep diri yang positif, (4) berani mengungkapkan pendapat saat berdiskusi, dan (5) berani menghadapi tantangan untuk menyelesaikan permasalahan.

\section{METODE}

Metode penelitian yang digunakan dalam penelitian ini adalah metode kualitatif dengan jenis penelitian studi pustaka. Penelitian studi pustaka adalah suatu jenis penelitian yang digunakan dalam pengumpulan informasi dan data secara mendalam melalui berbagai literatur, buku, catatan, atau hasil penelitian sebelumnya yang relevan untuk memperoleh jawaban dan landasan teori terhadap masalah yang akan diteliti.

\section{HASIL DAN PEMBAHASAN}

Berdasarkan prinsip dan karakteristik RME, maka dapat disusun langkah-langkah pembelajaran pendekatan RME dalam RPP sebagai berikut:

- Langkah 1. Memahami masalah kontekstual, karakteristik RME yang muncul adalah menggunakan masalah kontekstual sebagai titik tolak.

- Langkah 2. Menyelesaikan masalah kontekstual yaitu siswa mendeskripsikan, mengintrepetasikan dan memikirkan strategi pemecahan masalah.

- Langkah 3. Membandingkan dan mendiskusikan jawaban, karakteristik RME yang muncul adalah kontribusi dan interaksi dengan siswa.

- Langkah 4. Menyimpulkan, berdasarkan diskusi kelas dan interaksi antara siswa dan guru dan kesepakatan atas setiap perbedaan yang dihasilkan.

Langkah-langkah pembelajaran tersebut diimplementasikan melalui penggunaan bahan ajar matematika berbentuk LKS. Pembelajaran pada materi trigonometri belum memberikan peluang bagi siswa untuk merekontruksi pemahaman (Sugiantara, Sandra, \& Suparta, 2013). Sehingga, LKS berbasis RME ini didesain untuk membantu siswa dalam merekontruksi pengetahuannya terhadap konsep dasar trigonometri pada segitiga siku-siku. 


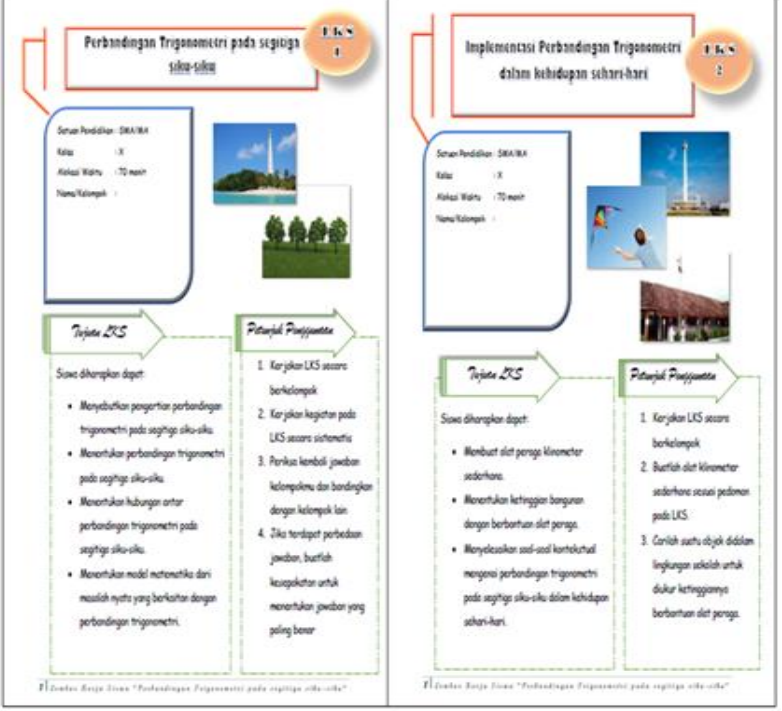

Gambar I Layour LKS berbasis RME

Gambar 1 menunjukan pendahuluan LKS berbasis RME, siswa diingatkan atau diperlihatkan terhadap sesuatu yang mungkin sudah tidak asing lagi yaitu bangunan Monas dan mercusuar, pohon, layang-layang dan tiang bendera sekolah. Hal tersebut sebagai langkah pertama pada sintaks pendekatan RME yaitu menyajikan atau memahami permasalahan kontekstual kepada siswa, dimana guru dapat memberikan apersepsi dengan mengajukan pertanyaan, seperti: "Saat libur panjang kemarin, adakah diantara kalian yang pergi ke Monas Jakarta atau pergi kepantai dan melihat mercusuar ditepi pantai?", "Apakah kalian pernah melihat anak kecil bermain layangan? Atau kalian juga pernah bermain layangan sewaktu kecil?", "Diantara kalian, adakah yang sedang mengikuti ekstrakurikuler paskibra disekolah dan pernah menjadi petugas pengibar bendera?, dan contoh pertanyaan sejenis lainnya. Kemudian menuju kegiatan inti, guru dapat bertanya kembali tentang, "Pernah terbayangkan tidak oleh kalian, bahwa hal-hal tersebut ada keterkaitannya dengan konsep trigonometri?". Karakteristik RME juga diperlihatkan dalam petunjuk penggunaan LKS, dimana LKS tersebut dikerjakan secara berkelompok, diperkenankan untuk membandingkan ide antar kelompok dan membuat kesepakatan, serta melakukan praktik disekitar lingkungan sekolah.

Pada dasarnya untuk mencapai tujuan pendidikan matematika yang lebih baik, pembelajaran matematika realistik memanfaatkan realitas dan lingkungan untuk mempermudah proses pembelajaran matematika. Realita dapat dimaknai sebagai hal-hal yang konkrit atau nyata sehingga siswa dapat mengamati, memahami dan membayangkan hal tersebut, sedangkan lingkungan dimaknai sebagai tempat siswa berada baik lingkungan sekolah, keluarga maupun masyarakat atau dapat diartikan juga sebagai lingkungan dalam kehidupan sehari-hari siswa.
Melalui pertanyaan-pertanyaan yang dihadirkan dan aktivitas belajar yang diciptakan tersebut maka siswa sedikit banyak akan menceritakan pengalamannya atas permasalahan tersebut, mereka akan termotivasi untuk mengetahui implementasi konsep materi yang akan mereka perlajari, dan turut aktif dalam aktivitas kelas melalui interaksi antar kelompok siswa dengan bimbingan guru. Hal tersebut sebagai upaya yang dapat mengaktifkan self-confidence siswa diantaranya adalah berani mengungkapkan pendapat saat berdiskusi.

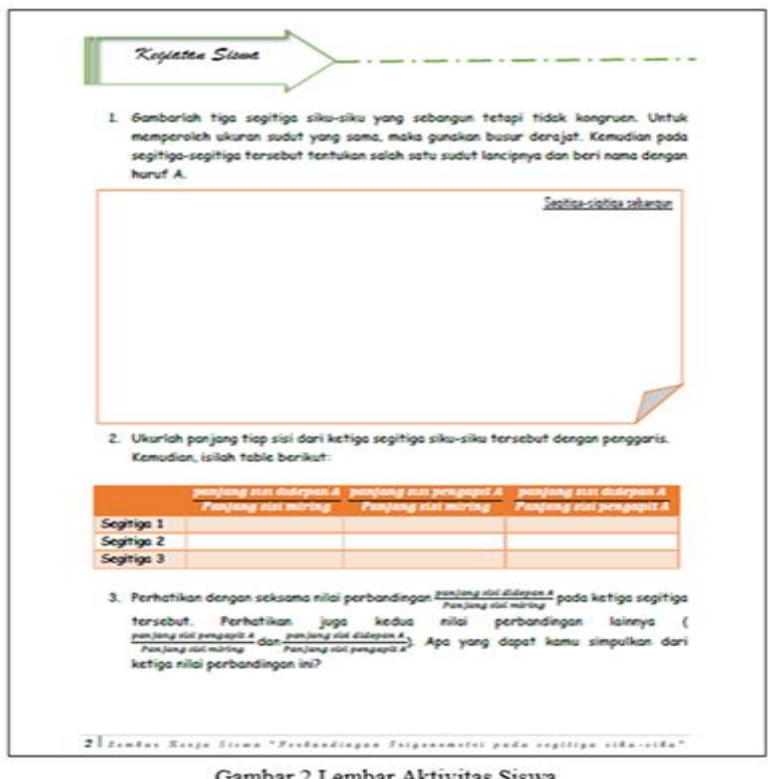

Pada bagian kegiatan siswa (Gambar 2), siswa diarahkan untuk menyelesaikan masalah kontekstual sesuai sintaks model pembelajaran RME. Hal tersebut diawali dengan mendeskripsikan permasalahan, seperti mengumpulkan informasi sesuai pemahaman siswa dengan cara mengingat materi prasyarat yaitu segitiga siku siku. Seringkali, materi prasyarat tidak diperhatikan dan guru kurang mengaitkan materi prasyarat yang harus dikuasai siswa tersebut dengan materi trigonometri saat proses pembelajaran, sehingga siswa hanya menghafalkan rumus dibanding mengembangkan pengetahuannya (Khotimah, Yuwono, \& Rahardjo, 2016). Melalui diskusi kelompok, pada tahap pertama siswa diarahkan untuk menggambar tiga segitiga siku-siku yang sebangun tetapi tidak kongruen. Tahap kedua, mengukur dan membandingkan panjang setiap sisi dari ketiga segitiga siku-siku tersebut. Aktivitas ini akan membimbing siswa untuk mengeksplorasi materi prasyarat pada materi trigonometri, karena pada dasarnya pendekatan RME akan mengaktifkan siswa untuk menghubungkan pemahaman yang telah ada sebelumnya sebagai materi prasyarat dengan pengetahuan baru sehingga memperoleh pemahaman konsep baru. Kemudian, tahap ketiga adalah siswa diberikan peluang untuk menguji hipotesis melalui 
kegiatan yang merekontruksi konsep trigonometri dan siswa dilatih untuk berani mengeluarkan gagasan dan ide. Tujuan aktivitas tersebut untuk memfokuskan dan memberikan tantangan kepada siswa untuk berani berpendapat serta menyimpulkan konsep trigonometri pada perbandingan segitiga siku-siku.

Hal tersebut sebagai upaya menumbuhkan selfconfidence siswa, melatih pemahaman konsep siswa dalam hal indikator kemampuan menyatakan ulang konsep trigonometri dan kemampuan mengklasifikasikan perbandingan trigonometri berdasarkan sifat tertentu yang telah di pahami siswa secara berkelompok. Tahap keempat adalah guru akan mengarahkan lebih spesifik dan menyimpulkan tentang ketentuan perbandingan sin, cos dan tan dalam segitiga siku-siku setelah siswa mengemukakan ide atau gagasannya sehingga siswa akan membandingkan dengan kesimpulan yang telah dibuat kelompoknya (Gambar 3).



Geaber 3 Lembe Alaritas Sisna

Setelah mengetahui definisi perbandingan trigonometri sin, cos dan tangen maka tahap kelima adalah siswa akan diarahkan kembali untuk merekontruksi pengetahuannya pada situasi baru mengenai konsep cosecant, secan dan cotangen, berdasarkan intruksi pada LKS dan melengkapi pada tabel yang disediakan. (Gambar 3). Tahap keenam adalah menyelidiki keterkaitan atau hubungan antara sin dan cosecant, cos dan secan serta tan dan cotangent. Tahap ketujuh dan kedelapan adalah tahap aplikasi, dimana siswa harus menyelesaikan masalah melalui pengaplikasian konsep yang telah ditemukan sebelumnya. Pada tahap ini, siswa harus mencari perbandingan trigonometri lain dengan hanya bermodalkan satu perbandingan trigonometri. Indikator pemahaman konsep yang hendak dicapai adalah kemampuan menyatakan ulang konsep trigonometri, kemampuan mengklasifikasikan perbandingan trigonometeri menurut sifat-sifat, kemampuan menyajikan konsep trigonometri dalam sketsa gambar segitiga sikusiku, dan kemampuan mengembangkan syarat perlu atau syarat cukup dari suatu konsep trigonometri. Kemudian, siswa diintruksikan untuk menuliskan fakta dan informasi penting, pertanyaan penting disertai alternatif penyelesaiannya sesuai indikator pemahaman konsep matematika tersebut.

Kemudian pada bagian selanjutnya siswa akan diperkenalkan dengan sebuah alat peraga yaitu klinometer sederhana (Gambar 4). Siswa akan dipandu untuk membuat alat klinometer sederhana tersebut dan melakukan praktik mengukur ketinggian suatu objek yang ada dilingkungan sekolah menggunakan alat peraga yang telah dibuat secara berkelompok. Kegiatan mengukur objek dilingkungan sekolah ini sebagai bagian dari mempraktikan atau membuat strategi berdasarkan sintaks pendekatan RME yaitu menyelesaikan masalah kontekstual, dan sebagai bentuk pemahaman konsep siswa terkait indikator memberi contoh yang berkaitan dengan materi yang sedang dipelajari. Setiap anggota kelompok akan menentukan objek, merancang alat peraga, menentukan strategi prosedur penggunaan alat peraga, saling mengamati dan membandingkan dengan kelompok lain. Hal tersebut sebagai suatu upaya menghadirkan pengalaman, membantu siswa memahami dan mengingat materi pelajaran, serta menumbuhkan rasa ingin tahu dan motivasi belajar.

Praktik ini akan membantu siswa menggunakan konsep yang telah dipahami untuk menyelesaikan permasalahan yang ada. Aktivitas belajar ini dirancang untuk dapat membangun pengalaman baru dan kepercayaan diri siswa yaitu percaya terhadap kemampuan diri, pengambilan keputusan secara mandiri, konsep diri yang positif, melakukan diskusi, saling bertukar gagasan atau ide dan berani menghadapi tantangan permasalahan. 


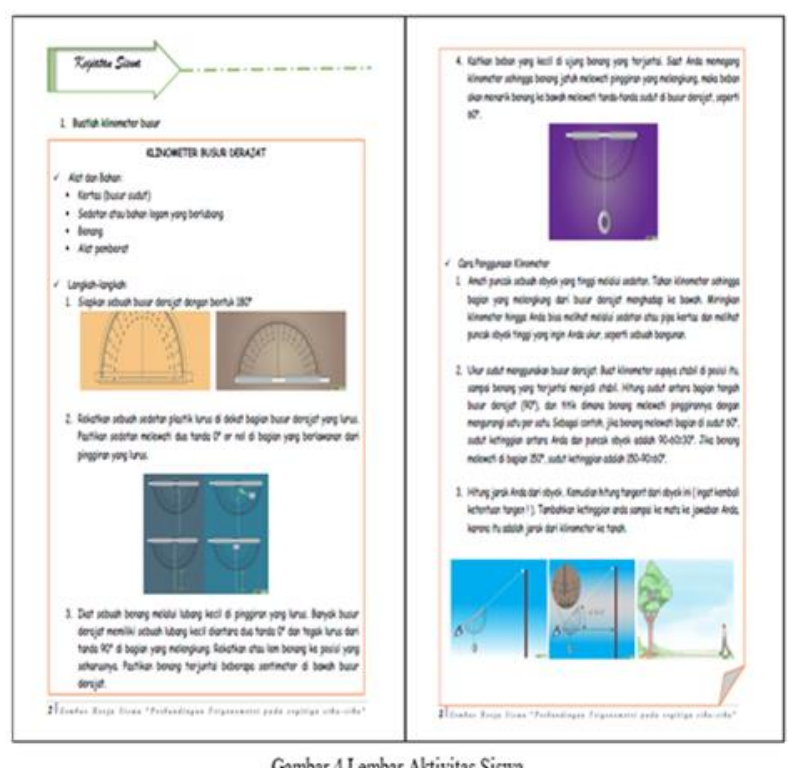

Gambar 4 Lembar Aktivitas Siswa

Pengalaman hidup dan kemampuan diri melakukan sesuatu dengan baik dapat menumbukan rasa percaya diri atau self-confidence siswa. Kepercayaan diri tersebut berpengaruh terhadap hasil belajar, sikap positif akan mendorong motivasi dan daya tarik siswa untuk menyukai belajar matematika. Hal tersebut diharapkan dapat mengoptimalkan prestasi belajar dan mengaktualisasikan segenap potensi siswa dalam pembelajaran matematika secara lebih baik.

Pada LKS ini juga disajikan beberapa soal kontekstual pemahaman konsep perbandingan trigonometri. (Gambar 5)

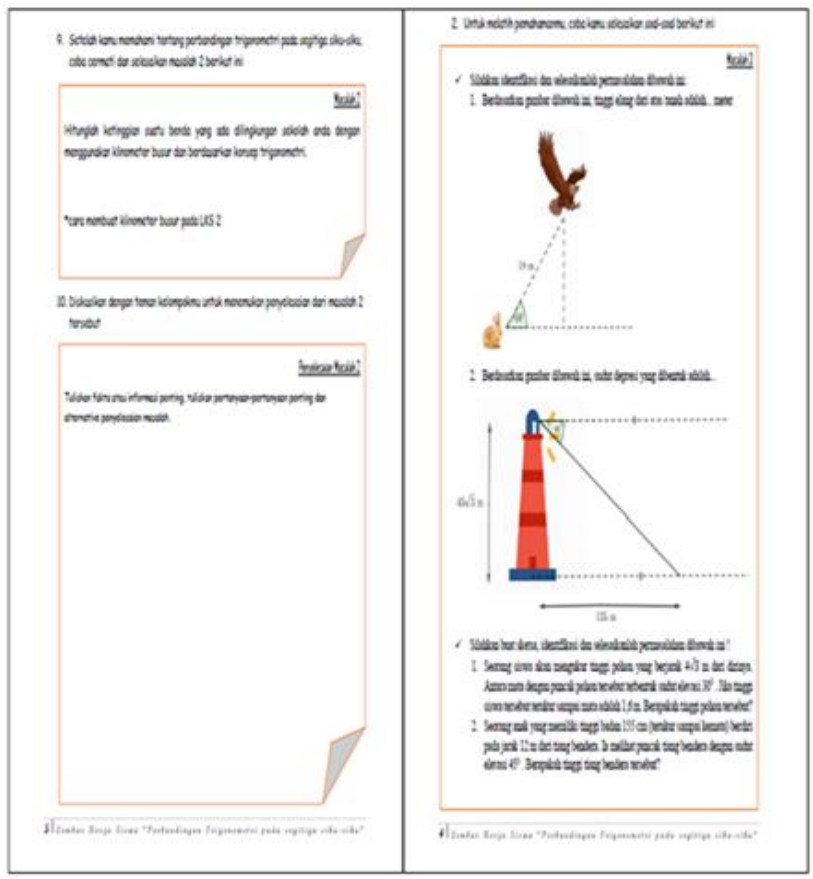

Gambar 5 Contoh Permasalahan

Sebagai bagian dari sintaks pendekatan RME yaitu membandingkan dan mendiskusikan, siswa diharapkan dapat menyelesaikan permasalahan dengan menyajikan konsep dalam berbagai bentuk representasi matematika seperti menuliskan kalimat matematika dari yang diketahui dan menyajikan permasalahan dalam bentuk gambar dengan benar, kemudian memilih atau menggunakan suatu prosedur secara tepat serta dapat mengimplementasikan konsep dalam menyelesaikan permasalahan. Melalui pengalaman yang telah didapatkan sebelumnya, siswa diharapkan dapat memecahkan jenisjenis masalah baru. Dengan semakin banyak berlatih, siswa diharapkan dapat memaksimalkan pemahaman konsep dasar trigonometri dan semakin terampil dalam menyelesaikan permasalahan matematika. Selain itu, pada tahap akhir siswa juga diintruksikan untuk membuat inti sari dari seluruh materi yang telah dibahas terkait konsep dan prinsip-prinsip yang telah siswa temukan dan kembangkan, hal tersebut sebagai bagian penutup dari sintaks pendekatan RME yaitu memberi kesimpulan.

Penelitian ini sesuai dengan pendapat yang dikemukakan Fitriani (2015) bahwa self-confidence siswa akan berkembang melalui model RME, karena siswa diarahkan untuk menyelesaikan permasalahan atau melakukan sesuatu sesuai pengetahuan dan pengalaman yang dimilikinya. Konsep-konsep atau pengetahuan matematika formal bersumber dari masalah-masalah realistik, hal tersebut dapat menciptakan aktivitas siswa yang mempengaruhi pemahaman konsep matematis siswa. Siswa mulai merintis kemampuan matematika manakala telah memahami konsep, apabila telah memiliki selfconfidence maka ketika dihadapkan kepada suatu masalah maka siswa akan percaya diri dalam menyelesaikannya. Melalui rangkaian kegiatan dalam LKS ini, siswa diberi kesempatan untuk mengidentifikasi, membangun konsep, mengungkapkan pertanyaan, berdiskusi untuk menyelesaikan permasalahan, dan mempresentasikan hasil diskusinya sehingga mengetahui konsep yang dipakai benar atau salah. Seluruh aktivitas tersebut diharapkan dapat memberi pengaruh positif terhadap pemahaman konsep matematika dan self-confidence siswa.

\section{KESIMPULAN}

Berdasarkan hasil penelitian tersebut maka dapat disimpulkan bahwa penerapan bahan ajar berbasis RME diharapkan dapat memberi pengaruh positif terhadap kemampuan pemahaman konsep matematis dan selfconfidence siswa, hal ini disebabkan karena:

1. Pendekatan pembelajaran RME diimplementasikan terhadap RPP dan bahan ajar berupa LKS dengan langkah-langkah pembelajaran sesuai dengan prinsip dan karakteristik RME.

2. Siswa diberikan kesempatan untuk membangun atau merekontruksi ide atau pengetahuan mereka sehingga 
memudahkan ketercapaian indikator-indikator pemahaman konsep matematis siswa.

3. Aktivitas pembelajaran dirancang secara interaktif, mengarahkan siswa pada kemampuan melakukan sesuatu dengan pengalaman dan pengetahuan yang dimilikinya sehingga dapat mengaktifkan selfconfidence siswa.

\section{REKOMENDASI}

Dari hasil penelitian ini diharapkan dapat menjadi alternatif dalam meningkatkan kualitas pembelajaran matematika di sekolah, khususnya mengenai pemahaman konsep matematis dan self-confidence siswa. Selain itu diharapkan terdapat penelitian lanjutan terkait penerapan pendekatan pembelajaran RME serta bahan ajar matematika untuk kemampuan matematis dan kemampuan kepribadian yang lainnya.

\section{DAFTAR PUSTAKA}

Agninditya, F., Sunandar, \& Purwanti, H. (2014). Analisis kesalahan dan kesulitan peserta didik dalam menyelesaikan soal uraian pokok bahasan trigonometri kelas X. Prosiding Mathematics and Sciences Forum. (pp. 795-798).

Badan Standar Nasional Pendidikan (BNSP). (2006). Model Penilaian Kelas. Jakarta: Depdiknas.

Balka, H., \& Miles, H. (2012). What is Conceptual Understanding?(Online),

(http://www.mathleadership.com/sitebuildercontent/ sitebuilderfiles/conceptualUnderstanding.pdf), diakses 28 Desember 2016.

Ekaputri, Y.N. (2016). Pengaruh model pembelajaran generatif terhadap pemahaman konsep peserta didik kelas VIII MTsN di Kabupaten Pesisir Selatan. Jurnal Kepemimpinan dan Pengurusan Sekolah, $1(1), 57-64$

Elianti, Maulina, R., \& Milizar. (2014). Penerapan model pembelajaran generative learning pada materi trigonometri di kelas X SMAN 4 Banda Aceh. Prosiding Seminar Nasional Pendidikan. (pp. 193199).

Fitriani, N. (2015). Hubungan antara Kemampuan Pemecahan Masalah Matematis dengan Selfconfidence Siswa SMP yang Menggunakan Pendekatan Pendidikan Matematika Realistik. Jurnal Euclid, vol.2, No.2. FPMIPA UNY.

Hendriana, H., Rohaeti, E. E.,Sumarmo, U. (2017). Hard Skills dan Soft Skills Matematik Siswa. Bandung: Refika Aditama.

Khotimah, K., Yuwono, I., \& Rahardjo, S. (2016). Kesulitan peserta didik dalam menyelesaikan soal perbandingan trigonometri. Prosiding Seminar Nasional Pendidikan Matematika Universitas Kanjuruan Malang, 1. (pp. 46-52).
Maryanti, A., (2013). Mebangun Self-Confidence Siswa dalam Pembelajaran Matematika dengan Pendekatan Problem Solving. Makalah Seminar Nsional

Miksalmina. (2013). Penguasaan siswa pada materi trigonometri di SMAN Darussalam Aceh besar. Jurnal Visipena, 4(2), 101-110.

Mulyono., Surya, E. (2006). Meningkatkan Aktifitas Dan Pemahaman Konsep Pembagian Pada Soal

Nabie, M.J., Akayuure, P., Ibrahim-Bariham, U.S.I., \& Sofo, S. (2018). Trigonometric concepts; pre-service teacher's perceptions and knowledge. Journal on Mathematics Education, 9(2), 169-182. https://doi.org/10.22342/jme.9.2.5261.169-182.

Ni Putu Eka Widiantari, Kartono, Ami Ariyani (2019). Meningkatkan Pemahaman Konsep Trigonometri Siswa Kelas XI MIPA 4 SMAN 11 Semarang Melalui Strategi PQ4R Berbantuan Kartu Soal. Prosiding Seminar Nasional Matematika. (pp. 7278).https://journal.unnes.ac.id/sju/index.php/prisma/

Nurdiyanto, T. (2019). Trigonometri Mengupas Konsep Dasar dan Pembelajarannya. Yogyakarta: Matematika Graha Ilmu.

Nurdiyanto, T., Hartono, Y., \& Indaryanti. (2020). Pengembangan LKPD materi trigonometri berbasis generative learning di kelas X. Jurnal Pendidikan Matematika, 14(1), 51-66. https://doi.org/10.22342/jpm.14.1.6798.51-66.

Ruseffendi, E. T. (1988). Pengajaran matematika untuk meningkatkan CBSA. Bandung: Tarsito.

Sugiantara, I. G., Sandra I. W., \& Suparta, I. N. (2013). Pengembangan Perangkat Pembelajaran Matematika Realistik dengan Peta Konsep pada Materi Trigonometri Kelas XI. e-Journal Program Pascasarjana Universitas Pendidikan Ganesha Program Studi Matematika, 2, 1-11.

Suherman, E., (2003). Evaluasi Pembelajaran Matematika. Bandung: Universitas Pendidikan Indonesia

Surya, E. (2011). Menjadi Guru Kelas Profesional Dalam Upaya Pembelajaran Siswa Yang Kreatif

Trianto. (2017). Mendesain Model Pembelajaran Inovatif, Progresif, dan Kontekstual. Jakarta: Kencana Prenada Media Group.

Winarni, S. (2016). Pembelajaran rumus-rumus trigonometri menggunakan lembar kerja peserta didik menurut prinsip konstruktivisme pada peserta didik kelas XI. Edumatica: Jurnal Pendidikan Matematika, 6(1), 9-14. https://doi.org/10.22437/edumatica.v6i01.2995.

Wulandari, I.G., \& Puspitadewi, K.R. (2015). Meningkatkan analisis kesalahan peserta didik dalam mengkontruksi konsep trigonometri. Jurnal Santiaji Pendidikan (JSP), 5(1), 18-25 